ELORE (ISSN 1456-3010), vol. 17 - 2/2010.

Julkaisija: Suomen Kansantietouden Tutkijain Seura ry.

[http://www.elore.fi/arkisto/2_10/mckeough1_2_10.pdf]

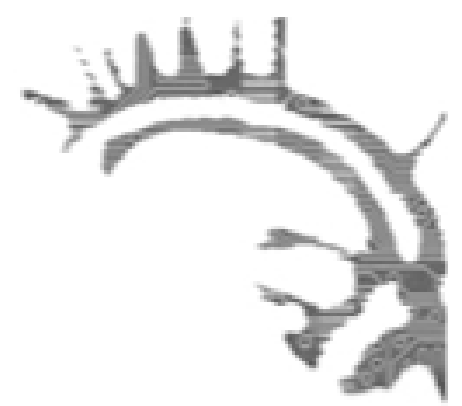

KiRJA-ARVIO

VUODEN I9I 8 SODAN KÄSITTELY PAIKALLISENA PROSESSINA

HEIMO, ANNE 2010: Kapina Sammatissa. Vuoden 1918 paikalliset tulkinnat osana historian ybteiskunnallisen rakentamisen prosessia. Suomalaisen Kirjallisuuden Seuran Toimituksia 1275. Helsinki: SKS. 295 sivua.

\title{
Andreas McKeough
}

Anne Heimo tarkastelee folkloristiikan alan väitöskirjassaan Kapina Sammatissa. Vuoden 1918 paikalliset tulkinnat osana historian ybteiskunnallisen rakentamisen prosessia vuoden 1918 sodan tapahtumien muistamista Sammatissa ja sen lähialueilla. Tutkimuksessa esitellään muistelemisen sekä paikallishistoriallisten käsitysten ja kertomusten sisältöjä, muotoja, taustoja, moninaisia yhteyksiä ja syntyjä. Heimo asettaa tutkimuksensa tavoitteeksi ensinnäkin sammattilaisten omien vuotta 1918 käsittelevien tulkintojen esittelyn, ja toiseksi historiakulttuuristen vaikutteiden ja sammattilaisten tulkintojen välisen vuorovaikutuksellisuuden tarkastelun. Näihin tavoitteisiin Heimo myös yltää tutkimuksessaan.

Matkallaan mainittuihin tavoitteisiin Anne Heimo muodostaa kattavan kuvan vuoden 1918 tapahtumista Sammatissa, siten kuin ne avautuvat tutkijalle sammattilaisten sodanjälkeisestä näkökulmasta. Heimon aineisto on kiitettävän laaja ja heterogeeninen. Se sisältää runsaasti haastatteluja, teemakirjoituksia, muistelmia, kalenterimuistiinpanoja, lehtikirjoituksia ja viranomaisasiakirjoja. Hän käsittelee sammattilaisten käsityksiä ja kerrontaa vuodesta 1918 historiantutkimuksen tuottaman tiedon omaksumisina, muistitietona ja näiden vuorovaikutuksen tuloksena. Tutkimuksen keskeinen teema on se, miten sotaan liittyvä muistitieto rakentuu ja välittyy paikallistasolla neuvottelevana ja kollektiivisena prosessina, joka on yhteydessä muun muassa historiantutkimukseen, sosiaalisiin tekijöihin, paikalliseen identiteettiin sekä välittäjiensä elämänhistorioihin. Heimo lähestyy muistamista ja muistelemista sosiaalisena, muihin yhteiskunnallisin ja kulttuurisiin toimijoihin nähden 
vuorovaikutuksellisena tapahtumasarjana, jota hän kutsuu - Jorma Kalelaa lainaten - historian yhteiskunnallisen rakentamisen prosessiksi. Tutkimuksessa tämän rakentumisprosessin osasista suurimman huomion saa paikkakuntalaisia järkyttäneitä tapahtumia ja ihmiskohtaloita käsittelevä muistitieto.

\section{REFLEKTIIVISTÄ MUISTITIETOTUTKIMUSTA}

Heimo pohjustaa tutkimuksensa perinpohjaisesti. Hän esittelee muistin, muistitiedon ja historiantutkimuksen teorioita ja tutkimustuloksia. Tämän lisäksi hän käsittelee laajalti vuoden 1918 sodan tutkimusta, sen erilaisia vaiheita sekä sodan kulkua Sammatissa ja sen lähialueilla. Tutkimuksen ensimmäiset viisi lukua ovatkin tutkimuksen taustaa, paikantamista sekä teoreettisia ja empiirisiä lähtökohtia käsitteleviä. Seuraavissa luvuissa Heimo suorittaa moniosaisen ja empiirisen analyysin, jossa hän tarkastelee muistelemisen subjektiivisuutta, historiakulttuurin ja paikallishistoriallisen asiantuntijuuden vaikutuksia muistitietoon ja kertomuksiin, sekä lopulta vuoden 1918 sodan sammattilaisten tulkintojen erityis- ja ominaispiirteitä. Kapina Sammatissa -tutkimusta on myös mahdollista lukea yleisemmin aineistolähtöisen tutkimuksen tekemisen prosessista kertovana narratiivina, sillä Heimo esittelee kiitettävästi tutkimuksen etenemisen sekä oman tutkijapositionsa kehittymisen vaiheita ja taustoja. Heimo on myös huolellinen siinä, että hän reflektoi omaa tutkimustaan ja sen eri osioita aiempaan tutkimukseen.

Heimo osoittaa lukeneisuuttaan ja ymmärrystään monien eri humanististen tieteenalojen tutkimussuuntauksista esimerkillisesti, semminkin kun hänen tutkimuksensa ei kuulu laajuudeltaan tiiliskiviluokkaan. Heimo paikantaa tutkimustaan suhteessa niin vuotta 1918 käsitteleviin tutkimuksiin kuin oman tieteenalaansa. Tutkimus ei ole aiheensa puolesta perinteisintä folkloristista tutkimusta. Lähimpänä folkloristisena tutkimuksena voidaan pitää Ulla-Maija Peltosen tutkimusta Punakapinan muistot (1996), jossa Peltonen tarkastelee punaisten tapoja muistella vuoden 1918 sotaa. Selkeitä yhtymäkohtia löytyy myös Peltosen toiseen työhön, Muistin paikat (2003), joka käsittelee sodassa ja sen seurauksena menehtyneiden muistamista. Heimo esitteleekin Peltosen tutkimuksia ja hyödyntää niitä monin paikoin omassaan. Tutkimuksen "folkloristisinta" antia on se, miten Heimo käsittelee vuoden 1918 sodan paikallisen muistitiedon suhdetta erilaisiin kertomusperinteen muotoihin ja sitä, miten tulkinnat sodasta kiteytyvät ajan myötä kertomuksiksi. Aiheensa, aineistojensa ja menetelmiensä kautta tutkimus ankkuroituu myös vahvasti muistitietotutkimuksen laajalle kentälle. 


\section{Aineistojen EHdoilla}

Tutkimuksen rakenne on looginen ja palvelee selkeän empiiristä painotusta. Siihen ei sisälly selkeärajaista teoreettista viitekehystä. Heimo kyllä esittelee runsaasti tutkimuksensa aiheisiin ja painotuksiin liittyvää teoreettista ajattelua, mutta paikoitellen nämä teoriat jäävät irrallisiksi tutkimuksen analyysiosioihin nähden. Luku tutkimuksen teoreettisista lähtökohdista onkin enemmän siihen liittyvän tutkimushistorian esittelyä kuin näiden tutkimusten ja niihin kytkeytyvän teorian varsinaista hyödyntämistä käsittelevä. On mielenkiintoista lukea tutkimuksen kannalta keskeisistä tutkimussuuntauksista, esimerkiksi kerronnan tutkimuksesta, mutta näiden suuntausten keskeissisältöjä voisi tällöin myös hyödyntää analyysissa eksplisiittisemmin. Tutkimuksessa ei ole myöskään konstruoitu ja selkeästi rajattu analyysimenetelmää, vaan Heimo operoi analyysissään lähinnä perinteisten laadullisten menetelmien, kuten teema-analyysin, avulla. Teoreettisen viitekehyksen ja ennen kaikkea analyysimenetelmän rajaamattomuus selittyvät kuitenkin tutkimuksen heterogeenisen aineistolla ja sen vaatimusten sanelemalla moniosaisella empirialla. Tutkimus onkin selkeän aineistolähtöinen. Lähtökohta on toimiva, vaikka tarkoittaakin teoreettisen panoksen suhteellista keveyttä.

Syyllisyys ja sankaruus ovat keskeisiä teemoja vuotta 1918 koskevassa sammattilaisessa muistitiedossa ja kertomuksissa. Syyllisiä ja sankareita löytyy paikallisissa tulkinnoissa niin punaisten kuin valkoistenkin riveistä. Myös paikallisuuteen ja ulkopaikkakunnallisuuteen sekä niiden välisiin yhteyksiin ja jännitteisiin liittyy paljon kerrontaa. Teloitukset ovat keskeisin asiasisältö sekä muistitiedossa että kertomuksissa. Heimo tarkastelee mielenkiintoisella tavalla myös paikallisten ja jaettujen tulkintojen muovautumista kertomuksiksi, esimerkiksi varatuomari Unto Nevalaisen ja emäntä Hulda Vannaksen surmien tapauksessa. Sammatin traagisia sotatapahtumia käsittelevä kerronta sisältää myös paljon reflektiota paikallisidentiteettiin ja -historiaan: monet kertojat korostavat, että ennen sotaa Sammatti - kansallissankari Elias Lönnrotin synnyinpitäjä - oli yhteiskunnallisesti harmoninen paikkakunta.

\section{MUISTITIEDON DYNAAMINEN JA PAIKALLINEN PROSESSUAALISUUS}

Heimon otteesta näkee, että hän tuntee aineistonsa perinpohjaisesti ja kykenee hahmottamaan sen suuria linjoja ja yhteyksiä. Hän yltää aineiston merkitysten erittelevään, vertailevaan ja niitä historiallisiin, sosiaalisiin ja kulttuurisiin ulottuvuuksiin kytkevään analyysiin. Tutkimuksen kautta lukijalle piirtyy selkeä ja kokonaisvaltainen kuva vuoden 1918 sodan tapahtumista Sammatissa sekä ennen kaikkea niiden muistelemisesta ja muistelun tulkinnallisuudesta. Paikallisuuden ja siihen ankkuroituvan näkökulman takia Heimon tutkimus tuo mieleen Risto Alapuron merkittävän teoksen Suomen synty paikallisena ilmiönä 1890-1933. Tutkimukset eroavat kuitenkin siinä, että Alapuro tarkastelee laajasti vuoden 1918 sodan vastakkainasettelun syntyä Huittisissa, kun taas Heimo keskittyy sodan muistelemisen ja muistamisen 
kysymyksiin Sammatissa. Alapuron tutkimuksen tavoin Heimon teoksessa avautuu kapean maantieteellisen rajauksen avulla toimiva näkökulma koko maata koskettaviin seikkoihin.

Syvällisen aineistolähtöisyyden lisäksi Heimon tutkimuksen parasta antia on kontekstualisoivan tutkimusotteen kautta avautuva näköala muistitiedon paikallisuuteen, prosessuaalisuuteen ja dynaamisuuteen, niin vuoden 1918 sodan kontekstissa kuin laajemminkin. Heimo ei pyri hahmottelemaan vuoden 1918 sodan muistelemisen ja muistamisen yleisten piirteiden synteesiä. Tämä on ymmärrettävää, sillä tutkimuksessa painottuu vahvasti heterogeenisen aineiston ehdoilla etenevä moniportainen empiria. Tutkimus kuvaa keskeisten muistelun teemojen lisäksi sitä, miten muistitiedon sisällöt ja painotukset elävät eri kertojien suissa ja ajan kuluessa, sekä sitä, miten historiantutkimus ja paikallinen asiantuntijuus vaikuttavat muistitietoon ja sen välittymiseen.

Heimo kirjoittaa selkeästi. Tutkimus on kauttaaltaan tyylillä ja harkiten laadittu. Tämä on ehdottoman tärkeä asia yleisestikin, mutta erityisesti tämänkaltaisen tutkimuksen kohdalla, joka todennäköisemmin kiinnostaa myös tiedemaailman ulkopuolella leipäänsä hankkivia, niin sammattilaisia kuin vuoden 1918 sodasta muuten kiinnostuneita.

\section{KIRJALLISUUS}

ALAPURO, RISTO 1994: Suomen synty paikallisena ilmiönä 1890-1933. Helsinki: Hanki \& Jää.

PELTONEN, ULLA-MAIJA 1996: Punakapinan muistot. Tutkimus työväen muistelukerronnan muotoutumisesta vuoden 1918 jälkeen. Suomalaisen Kirjallisuuden Seuran toimituksia 657. Helsinki: SKS.

PELTONEN, ULLA-MAIJA 2003: Muistin paikat. Vuoden 1918 sisällissodan muistamisesta ja unohtamisesta. Suomalaisen Kirjallisuuden Seuran toimituksia 894. Helsinki: SKS.

Filosofian maisteri Andreas McKeough on folkloristiikan jatko-opiskelija Helsingin yliopistossa. 